\title{
O twórczości Kazimiery Itłakowiczówny. Materiał archiwalny z zespołu Głównego Urzędu Kontroli Prasy, Publikacji i Widowisk z połowy 1955 roku
}

Kamila Budrowska

(Uniwersytet w Białymstoku)

\section{WSTĘP}

„Biuletyn Informacyjno-Instrukcyjny” nr 7, z którego pochodzi opracowany materiał, opublikowany został latem roku $1955^{\mathrm{I}}$.W Głównym Urzędzie Kontroli Prasy, Publikacji i Widowisk ${ }^{2}$ to czas niespokojny, zdecydowanie odwilżowy, w wewnętrznych dokumentach pojawiają się zatem informacje wyjaśniające dynamicznie zmieniającą się sytuację polityczną oraz wskazówki, jak oceniać utwory niepublikowanych wcześniej pisarzy. Do takiej grupy zaliczyć można także tekst Kazimierza Królika O twórczości Kazimiery Ittakowiczówny ${ }^{3}$. Niewiele jest w numerach z lat pięćdziesiątych rozpraw poświęconych poszczególnym twórcom; widomy to znak, że w połowie roku 1955 postać i dorobek autorki Stowika literwskiego zyskały w urzędzie status priorytetowy - a może również problemowy.

Za bezpośrednią przyczynę powstania przeglądu uznać można ogłoszenie, a więc uprzednie dopuszczenie do publikacji dwóch jej tomików. Poezje. 1940-1954 $4^{4}$ wydał

1 Szerzej na temat „Biuletynów” z początków lat pięćdziesiątych zob. K. Budrowska, Wewnętrzne pismo cenzury. „Biuletyn Informacyjno-Instrukcyjny w latach 1952-1955, w: eadem, Studia i szkice o cenzurze w Polsce Ludowej w latach 40. i 50. XX wieku, Białystok 2014, s. 95-106.

2 W dalszej części artykułu skrót GUKPPiW.

3 AAN, GUKPPiW, 420, teczka 165/4, s. 18-30.

4 K. Iłłakowiczówna, Poezje. 1940-1954, PAX, Warszawa 1954. Ze względu na tematykę opracowania w przypisie każdorazowo podany zostaje wydawca. 
pod koniec roku 1954 Instytut Wydawniczy Pax, a Wiersze religijne. 19I2-I954 ${ }^{5}$ poznańskie wydawnictwo Albertinum rok później. Cenzor Królik ogłasza artykuł jeszcze zanim Wiersze religijne się ukażą (stopka głosi, że do druku skierowano je w październiku i955 r., a druk ukończono w listopadzie I955 r.), z czego można wnosić, że miał wgląd do egzemplarza przedstawionego do kontroli, a być może sam go cenzurował.

Przeanalizowane przez Kazimierza Królika tomy z połowy lat pięćdziesiątych nie były jedynymi wydanymi po wojnie przez poetkę. Zbiór Wiersze wybrane. $1912-1947^{6}$ z posłowiem Wilhelma Szewczyka ogłosiło w lipcu 1949 r. prywatne wydawnictwo Władysława Bąka. Należy podkreślić, że był to „ostatni moment” na tego typu przedsięwzięcie - zaostrzenie cenzorskich kryteriów ewaluacji nastąpiło wczesną jesienią 1948 r., do połowy roku następnego ukazywały się pojedyncze tytuły, które uzyskały zgodę na druk jeszcze przed zmianami.

W zespole archiwalnym, w którym znajduje się interesujący nas „Biuletyn Informacyjno-Instrukcyjny”, udało się odnaleźć także ślad zaniechanego wydania zbioru Kazimiery Iłłakowiczówny z końca lat czterdziestych. W maju 1948 r. Wydawnictwo Zachodnie przesłało bowiem do oceny Wiersze wybrane, zawierające utwory z lat I912-I945. Projektowany nakład miał wynieść 5600 egzemplarzy. Recenzje datowane są na 20 maja i 6 czerwca I 948 roku i mają pozytywne oceny, cenzorzy proponują jednak liczne ingerencje. Jeden z pracowników GUKPPiW zachęca do usunięcia aż I9 wierszy o tematyce religijnej oraz związanej w Wilnem.

Ostatecznie, po pertraktacjach z wydawnictwem i poetką „bardzo trudną we współpracy", jak zaprotokołowano w raportach, usunięto dwa wiersze Do Wilna (pochodzący z tomiku Z głębi serca z 1928) oraz Rosjanka (z wojennego budapesztańskiego tomu Wiersze bezlistne z 1942). Utwór Do Wilna (pióra urodzonej w tym mieście autorki) nie został zaakceptowany z powodu tematyki kresowej, a pesymistyczne passusy, jak „[teraz] [...] wilczyska ciebie obiegły”, z pewnością tylko przypieczętowały nieprzychylną decyzję. Liryk Rosjanka okazał się najbardziej kłopotliwy: przedstawiony w nim dramatyczny los radzieckich kobiet sprawit, że tekst skutecznie wyeliminowano z obiegu, powtórnie zaistniał w druku dopiero po zniesieniu cenzury, w Poezjach zebranych wydanych pod koniec lat dziewięćdziesiątych?

Druga $\mathrm{z}$ recenzji, z czerwca 1948 roku, uwzględnia najwyraźniej negocjacje z autorką, gdyż proponuje usunięcie tylko dwóch wzmiankowanych wierszy. Zachowawcza konkluzja otwiera zbiorowi drogę do druku:

5 Eadem, Wiersze religijne. 1912-1954, przedm. Z. Pędziński, Albertinum, Poznań, 1955.

6 Eadem, Wiersze wybrane. 1912-1947, posł. W. Szewczyk, W. Bąk, Łódź 1949.

7 Eadem, Rosjanka, w: eadem, Poezje zebrane, zebrali, oprac. i bibliogr. sporządzili J. Biesiada, A. Żurawska-Włoszczyńska, wstęp J. Ratajczak, Toruń 1999, t. 2, s. 718. 


\section{\Wiersze Iłłakowiczówny nie zawierają w zasadzie rzeczy, które dałyby podstawę do odmowy wydania zezwolenia na druk, ale nie zawierają też żadnej z tych wartości, które składają się na znaczenie literatury jako oręża w walce o nowego człowieka ${ }^{8}$.}

$\mathrm{Na}$ opinii widnieje akceptacja zwierzchnika.

Nasuwa się zatem oczywiste pytanie, dlaczego do publikacji nie doszło. Można ostrożnie domniemywać, że przyczyniły się do tego kłopoty wydawcy. Wydawnictwo Zachodnie, o rodowodzie jeszcze przedwojennym, podzieliło los innych oficyn prywatnych, wykluczanych z rynku przez niekorzystne przepisy: „Dekret o zawieszeniu mocy niektórych umów wydawniczych w dziedzinie literackiej” z 1946 roku, który unieważniał na pięć lat uprawnienia wynikające z praw autorskich do wydawania dzieł klasyków, oraz „Rozporządzenie Rady Ministrów w sprawie koncesjonowania przedsiębiorstw wydawniczych” z 2I września 1949 roku, na podstawie którego wydawnictwa prywatne musiały się każdorazowo starać o specjalną koncesję wydawniczą ${ }^{9}$. Kwestia ta wymaga jeszcze dalszych badań, tu została tylko zasygnalizowana.

W latach stalinowskich utwory Iłłakowiczówny drukowane być nie mogły, podobnie jak innych autorów o „niepewnej” politycznie przeszłości, wyraźnie antyradzieckich poglądach czy jawnych związkach z Kościołem. Poetka spełniała wszystkie te „kryteria” i została objęta formalnym bądź nieformalnym „zapisem” ${ }^{\text {. }}$ Status wyjątku miały tylko jej tłumaczenia: głównie z rosyjskiego, francuskiego i niemieckiego, z których publikacji się utrzymywała.

Jak stwierdził w I955 na łamach „Tygodnika Powszechnego” Bronisław Mamoń, nie wydając osobnej książki poetyckiej, popadała Iłłakowiczówna stopniowo w czytelnicze i społeczne zapomnienie. Dość wspomnieć, że władze przywiązujące do takich gestów duże znaczenie w żaden sposób nie uhonorowały jubileuszu pięćdziesięciolecia jej twórczości, które przypadało w 1954 roku ${ }^{\mathrm{II}}$.

Nieobecność Iłłakowiczówny w przestrzeni publicznej jako pisarki nie była jednak pełna, bibliografia zawartości czasopism notuje bowiem kilkanaście wierszy jej autorstwa ogłoszonych w czasopismach w latach 1950-I954, przede wszystkim w katolickich „Tygodniku Powszechnym” i „Dziś i Jutro”. Wzięła także autorka Stowika literwskiego udział w słynnej ankiecie „Pisarze wobec dziesięciolecia”,

8 AAN, GUKPPiW, sygn. 169, k. 54.

9 S.A. Kondek, Wtadza i wydawcy. Polityczne uwarunkowania produkcji książek w Polsce w latach 1944-1949, Warszawa 1993, s. 66-71.

10 „Zapisy” z lat czterdziestych i pięćdziesiątych w archiwach się nie zachowały, stąd niemożliwe jest sprawdzenie stopnia formalizacji zakazu.

11 B. Mamoń, O wierszach Ittakowiczówny, „Tygodnik Powszechny” 1955, nr 15, s. 12 i 15. 
ogłoszonej przez „Nową Kulturę” i w numerze z 2I marca I954 r. opublikowała krótką (i bardzo wstrzemięźliwą w ocenach) wypowiedź na temat powojennej Polski. W socjalistycznej rzeczywistości dostrzegała trzy elementy pozytywne: likwidację bezrobocia, upowszechnienie szkolnictwa wszystkich szczebli, dostępność książki i umasowienie czytelnictwa ${ }^{\mathrm{I} 2}$.

Wydaje się zatem, że „zapis”, który nie obejmował pojedynczych liryków drukowanych w prasie katolickiej, stopniowo łagodzono od początku roku 1954, by - przez publikację wyborów poezji najpierw w niskonakładowych wydawnictwach chrześcijańskich, potem w państwowym PIW-ie (w wydaniu z 1956 znalazły się także nieliczne wiersze powojenne) - dojść do wydrukowania prozy poetyckiej $Z$ rozbitego fotoplastykonu ${ }^{\mathrm{I3}} \mathrm{W} \mathrm{I} 957 \mathrm{r}$. oraz tomu Lekkomyślne serce ${ }^{\mathrm{I4}} \mathrm{W}$ I959, złożonego już w pełni z tekstów napisanych po wojnie.

Notatka O twórczości Kazimiery Ittakowiczówny znamionuje dość dużą wiedzę autora na temat biografii i dzieł poetki. Wprawdzie nie brak tu błędów (z najpoważniejszym, przypisującym wydanie Wierszy religijnych Pallotinum, na czele), ale widać, że autor sięgnął zarówno do tekstów (w tym także wydanych przed wojną), jak i opracowań z bieżącej prasy literackiej. Przeczytał też wstępy do wydań powojennych. Najobficiej posiłkował się autobiografią pisarki z okresu jej sekretarzowania Piłsudskiemu, przygotowaną z myślą o młodym odbiorcy - Ścieżka obok drogi. Sporo to mówi o jego horyzoncie intelektualnym, a także o popularności książki.

Co ciekawe, cenzor Królik przywołuje w całości i komentuje w „Biuletynie” utwór, który nie był publikowany do połowy roku 1955 ani w tomikach, ani w prasie: Wiersz na styczeń 1944 ogłoszono dopiero w tomie z 1959 r. Można zatem przypuszczać, że tekst ten został znacznie wcześniej przedstawiony do kontroli i nie zyskał akceptacji.

W szkicu tendencyjnie rysuje się sylwetkę oraz dorobek autorki Ikarowych lotów, podkreślając jej „bezgraniczne i ślepe wprost uwielbienie dla późniejszego Marszalka” oraz „bezgraniczną głupotę” w ocenie Związku Radzieckiego. Ocena polityczna wierszy także nie wypada pomyślnie: poetka nie napisała żadnego utworu, który afirmowałby Polskę Ludową, a w wielu przebijają „nutki tęsknoty, oczekiwania dawnej szlacheckiej świetności i szumu husarskich skrzydeł”. Autor konkluduje:

\section{》O tym, jak silna była nienawiść do młodego państwa radzieckiego, świadczą jej pozbawione wprost sensu i trzeźwości utwory nacechowa- ne bezgraniczną głu potą i wymysłami, wzorowanymi zresztą}

12 K. Iłłakowiczówna, Pisarze wobec dziesięciolecia, „Nowa Kultura” 1954, nr 12, s. 3.

13 Eadem, Z rozbitego fotoplastykonu. [Proza poetycka], PIW, Warszawa 1957.

14 Eadem, Lekkomyślne serce. [Wiersze], Czytelnik, Warszawa 1959. 
na oficjalnej propagandzie i oszczerstwach kół rządzących Polski sanacyjnej. [...]

Dlatego też fakt pozytywnych stron w twórczości Iłłakowiczówny [takich jak oparcie wypowiedzi poetyckiej na wzorcach ludowej pieśni i gawędy - K. B.] nie może przesłaniać tego, z czym absolutnie zgodzić się nie możemy ${ }^{15}$.

Warto w tym miejscu zapytać, czy artykuł Królika wpłynął na późniejszy sposób cenzurowania wierszy poetki, czyli - czy spełnił swą funkcję instruktażową.

We wrześniu 1955 r., dwa miesiące po ukazaniu się numeru 7 „Biuletynu Informacyjno-Instrukcyjnego", do GUKPPiW trafia kolejny tom Iłłakowiczówny, tym razem zgłoszony przez wydawnictwo prestiżowe i państwowe - Państwowy Instytut Wydawniczy. Wybór wierszy ${ }^{16}$ doczekał się dwóch bardzo szczegółowych opinii, sugerujących liczne zmiany. Autorem jednej z nich jest znów Kazimierz Królik, który zauważa, nie bez lekkiego zdziwienia:

\Oceniając niniejszy zbiorek pod względem politycznym, należy stwierdzić, że nie zawiera on prawie żadnych wierszy o wyraźnie wrogich elementach (gloryfikacja Piłsudskiego, nienawiść do Związku Radzieckiego), tak charakterystycznych dla twórczości Iłłakowiczówny $\mathrm{z}$ lat okresu międzywojennego ${ }^{\mathrm{I} 7}$.

Wybór wierszy oddano do składu I5 września I955 roku, po uwzględnieniu zalecanych ingerencji dotyczących przedruków z tomu Kolędy polskiej biedy. W wigilie powrotu (I9I7) - nie znalazł się w nim ani jeden tekst z tego zbioru. Podobnie - ani jeden utwór $\mathrm{z}$ tomów poświęconych marszałkowi Piłsudskiemu.

Recenzję wtórną przygotowuje w lutym I956 roku towarzysz Papiernik. Pisze o tych samych trudnościach, które sygnalizował autor O twórczości Kazimiery Ittakowiczówny:

\Silne akcenty religijne tej poezji, akcenty, których państwowe wydawnictwo nie ma potrzeby propagować, również napewno [sic!'] utrudniały pracę nad dokonaniem tego wyboru.

$\mathrm{Na}$ koniec cenzor stwierdza, iż autorka nie należy do „entuzjastek naszego ustroju”. Papiernik zatrzymuje ostatnie strony tomiku z zakończeniem wiersza Śnito mi się, 
datowanego pod tekstem na I955 roku, z którego wynika, że lepiej śnić o smutnej rzeczywistości, niż się zbudzić i zobaczyć, jak w Polsce jest naprawdę. Pierwsza decyzja naczelnika urzędu cenzury jest zgodna z jego propozycją, ale trzy dni później urząd godzi się na wydanie bez cięć. Zmiany zaproponowane uprzednio przez cenzora Królika zostają jednak utrzymane i wydany po raz pierwszy po długiej przerwie w państwowym wydawnictwie tomik Kazimiery Iłłakowiczówny trafia do czytelników w postaci zasadniczo niezgodnej z pierwotnym zamysłem autorki.

\section{ZASADY EDYCJI}

W opracowywanym materiale dokonano modernizacji ortografii i interpunkcji, pozostawiono niezmienioną składnię. Zachowano oryginalne podkreślenia. Błędy rzeczowe oraz fragmenty odzwierciedlające specyficzny światopogląd autora oznaczono [sic!]. Tytuły tekstów literackich wyróżnione cudzysłowem - oddano kursywą. Uzupełniono brakujące cudzysłowy i kursywy. Zachowano charakterystyczną delimitację tekstu, korygując wcięcia.

Przywoływane fragmenty tekstów Kazimiery Iłłakowiczówny zestawiono z wersjami z wydania krytycznego. Poprawiono niezgodności z oryginałem: brakujące fragmenty dopisano w nawiasie kwadratowym, przy nieprecyzyjnym cytacie wersje prawidłową podano obok w nawiasie kwadratowym, milcząco skorygowano błędy interpunkcyjne i literówki.

\section{Materiat ARChiwalny}

\section{O twórczości Kazimiery Ittakowiczówny}

Ponieważ stosunkowo obfity dorobek poetycki Iłłakowiczówny jest u nas mało znany, a w ostatnich czasach niektóre wydawnictwa katolickie czynią usilne próby wydania części jej wierszy (PAX 1954, Pallotinum [sic!] I955), zachodzi potrzeba zwrócenia uwagi na dorobek poetycki poetki oraz problematykę jej twórczości. Orientacja ta jest potrzebna w konkretnej pracy cenzorskiej.

Kazimiera Iłłakowiczówna urodziła się w $1892 r^{18}{ }^{18}$ W Wilnie. Swą karierę poetycką rozpoczyna w $1904 \mathrm{r}^{\mathrm{I9}}$ drukowanym w „Tygodniku Ilustrowanym” wierszu Jabtonie.

18 Informacje podane przez cenzora zestawione zostały z biogramem i bibliografią pisarki sporządzonymi przez Beatę Dorosz, w: Wspótcześni polscy pisarze i badacze literatury. Stownik biobibliograficzny, t. 3, red. J. Czachowska i A. Szałagan, Warszawa 1994, s. 294-299. Podana w biogramie data urodzenia to 6 sierpnia 1888 r., data 19 sierpnia 1892 r. określona jest jako „data urodzenia w dokumentach”.

19 Właśc. 1905. 
Debiutuje tomikami Ikarowe loty (I9I2) ${ }^{20}$ i Wici (I9I4) ${ }^{21}$. W I9I7 r. wydaje następne zbiory: Trzy struny ${ }^{22}$ i Kolędy polskiej biedy ${ }^{23}$, będące plonem wojennych przeżyć i doświadczeń, a w I9I9 r. Bajecznq historię o królewiczu La-fi-czaniu²4. W 1922 r. ukazuje się Śmierć Feniksa $a^{25}$ a w I923 zaś Rymy dziecięce ${ }^{26}$. Rok 1926 przynosi Potów ${ }^{27}$ i Obrazy imion wróżebnych [sic! ] $)^{28}$. Dalsze lata obfitują w następujące zbiorki: Ztoty wianek $^{29}$ (1927), Zwierciadto nocy ${ }^{30}$ (1927), Z gtębi serca ${ }^{3 \mathrm{I}}$ (1928), Ptaczacy ptak ${ }^{32}$ (1929), Czarodziejskie zwierciadetka 33 (1929), Popiót i perty ${ }^{34}$ (1930), Ballady bohaterskie 35 (1933), Stowik literwski ${ }^{36}$ (I936) oraz tomik wierszy dla dzieci pt. Wesote wierszyki37 (I934). Tak przedstawia się jej dorobek poetycki do 1939 r. w porządku chronologicznym ${ }^{38}$.

Swą intensywną twórczością poetycką zyskuje sobie Iłłakowiczówna stosunkowo duże uznanie krytyki, zadokumentowane [sic!] dwoma nagrodami: Miasta Wilna (1930) oraz nagrodą państwową (1935)

Czasy okupacji spędza poetka w Rumunii - w Siedmiogrodzie ${ }^{40}$. W ramach tzw. Biblioteki polskiej wydaje w Budapeszcie Wiersze bezlistne (194I) ${ }^{4 \mathrm{I}}$ oraz tłumaczy

20 K. Iłłakowiczówna, Ikarowe loty. [Wiersze], „Książka”, Kraków 1908.

21 Eadem, Wici. Cieniom roku 1914 poświęcone. [Wiersze], Gebethner i Wolff, Warszawa 1914.

22 Eadem, Trzy struny [Wiersze], Skład główny Księgarni Polskiej, Piotrogród 1917.

23 Eadem, Kolędy polskiej biedy. (W wigilię powrotu). [Wiersze], Praca, Piotrogród 1917.

24 Eadem, Bajeczna historia o królewiczu La-fi-Czaniu, o żotnierzu Soju i o dziewczynce Klio. [Powieść dla dzieci], E. Wende i Sp., Warszawa 1918.

25 Eadem, Śmierć Feniksa. [Wiersze], Ignis, Warszawa 1922.

26 Eadem, Rymy dziecięce. [Wiersze], K. Stryjeński, Kraków 1922.

27 Eadem, Potów [Wiersze], J. Mortkowicz, Warszawa 1926

28 Eadem, Obrazy imion wróżebne [Wiersze], Hoesick, Warszawa 1926.

29 Eadem, Opowieść o moskierwskim męczeństwie [Poemat]; Ztoty wianek [Wiersze], Hoesick, Warszawa 1927.

30 Eadem, Zwierciadto nocy [Wiersze], J. Mortkowicz, Warszawa 1928 (antydatowane 1927).

31 Eadem, Z gtębi serca [Wiersze], Gebethner i Wolff, Warszawa 1928.

32 Eadem, Ptaczacy ptak [Wiersze], Hoesick, Warszawa 1927.

33 Eadem, Czarodziejskie zwierciadełka. 50 wróżb wierszem, Księgarnia św. Wojciecha, Poznań 1928.

34 Eadem, Popiót i perty [Wiersze], Hoesick, Warszawa 1929.

35 Eadem, Ballady bohaterskie [Wiersze], Ossolineum, Lwów 1934 (antydatowane 1933).

36 Eadem, Stowik literwski. Poezje, Gebethner i Wolff, Warszawa 1936.

37 Eadem, Wesote wierszyki, Gebethner i Wolff, Warszawa 1934 (antydatowane 1933).

38 Królik pomija: Wiersze o Marszatku Pitsudskim. 1912-1935, Główna Księgarnia Wojskowa, Warszawa 1936 oraz Ścieżkę obok drogi, Towarzystwo Wydawnicze Rój, Warszawa 1939.

39 Właśc. Państwową Nagrodę Literacką.

40 Znalazła się tam we wrześniu 1939 r. i spędziła 8 lat; za: I. Molnar, Kazimiera Itłakowiczówna a język i literatura wegierska, w: $Z$ dziejów polsko-wegierskich stosunków historycznych i literackich, red. I. Csaplaros, A. Sieroszewski, Warszawa 1978, s. 190.

41 K. Iłłakowiczówna, Wiersze bezlistne. Zbiór poezji z lat 1936-1941, Komitet Obywatelski dla Spraw Opieki nad Uchodźcami Polskimi na Węgrzech, Budapeszt 1942. 
wybory poezji Andrzeja [sic!] Ady (1942) i Ludwika [sic!'] Aprili (1943) ${ }^{42}$. Po wojnie - w 1947 - wraca do kraju, gdzie poza Wyborem poezji (1949) ${ }^{43}$ nie wydaje żadnego zbioru nowych wierszy, ograniczając się do wydań wybranych wierszy z całokształtu jej twórczości poetyckiej Poezje 1940-I954 - PAX (I954), Wiersze religijne - Pallotinum (I955) [sic! ].

Okres pobytu w Polsce Ludowej to przede wszystkim praca nad przekładami. W 1948 r. wydaje w Książce i Wiedzy Arona Tomasi Alek na puszczy [sic!']44 i Dale Carnegie Jak uszczęśliwiać i być szczęśliwymm ${ }^{45}$. Poświęcając się coraz bardziej pracy przekładowej, Iłłakowiczówna tłumaczy W bukowińskiej puszczy Sandora Lestyana, Egmonta [sic!] Goethego, Don Carlosa Schillera oraz Annę Kareni$n e$ Lwa Tołstoja ${ }^{46}$. Przekłady jej stoją na wysokim poziomie i zyskują nagrodę PEN Clubu (1954) 47 .

Tyle encyklopedycznych danych o twórczości Iłłakowiczówny. Nas zainteresuje oprócz tego jeszcze dość bogaty dorobek twórczy, mniej znany młodemu pokoleniu.

Faktyczna droga życiowa Kazimiery Iłłakowiczówny przedstawia się następująco.

Dzięki temu, że siostra jej w okresie przed pierwszą wojną światową była osobistą sekretarką Piłsudskiego, Iłłakowiczówna utrzymywała z nim bardzo bliskie stosunki, które z czasem przerodziły się w bezgraniczne i ślepe wprost uwielbienie dla późniejszego Marszałka. Uwielbienie to dochodzi do tego stopnia, że podczas wojny, będąc w Wielkiej Brytanii w służbie sanitarnej, porwana entuzjazmem do Legionów, pisze list do Piłsudskiego z prośbą o przyjęcie jej do wojska. Równocześnie pisze wiersz Trzy struny (od którego nosi tytuł późniejszy zbiorek) i przeznacza go na hymn uwielbianych Legionów ${ }^{48}$. Gorące te prośby zostały ku rozpaczy Iłłakowiczówny zlekceważone przez Piłsudskiego jako niedorzeczne wymysły rozegzaltowanego umysłu.

42 Szerzej na ten temat: I. Molnar, op. cit., s. 189-196. E. Ady, Wybór poezji, przedm. I. Keviczky, sł. wst. S. Vincenz, Biblioteka Polska w Budapeszcie, Budapeszt 1943; L. Āprily, Wybór poezji, tłum. K. Iłłakowiczówna, J. Kot, S. Vincenz, Biblioteka Polska, Budapeszt 1943.

43 K. Iłłakowiczówna, Wiersze wybrane. 1912-1947, op. cit.

44 A. Tamasi,Abel w puszczy. [Powieś́'], cz. 1-2, Wiedza, Warszawa 1948. Był to przedruk budapesztańskiego wojennego wydania z $1943 \mathrm{r}$.

45 D. Carnegie, Jak uszczęśliwiać innych i być szczęśliwym?, streściła K. Iłłakowiczówna, Albertinum, Poznań 1948.

46 S. Lestyan, $W$ Bukowińskiej Puszczy. [Opowieś́ przygodowo-przyrodnicza dla mtodzieży], tłum. i przyp. K. Iłłakowiczówna, Nasza Księgarnia, Warszawa 1953; J.W. Goethe, Egmont. Tragedia, oprac. Z. Ciechanowska, Ossolineum, Wrocław 1956; F. Schiller, Don Carlos. Poemat dramatyczny, PIW, Warszawa 1954 (jest to przedruk wydania Gebethnera i Wolffa z 1933 r.); L. Tołstoj, Anna Karenina. Powieś́, t. 1, 3-4, PIW, Warszawa 1952-1953.

47 Nagroda PEN Clubu za przekłady z literatury obcych.

48 K. Iłłakowiczówna, Trzy struny, z tomu Trzy struny, w: eadem, Poezje zebrane, op. cit., t. 1, s. 153; do wiersza dedykacja: „Józefowi Piłsudskiemu”. 
W czasie wojny dostaje się do Rosji i tam właśnie w I9I7 r. wydaje Kolędy polskiej biedy oraz zbiorek Trzy struny z niedoszłym hymnem Legionów na czele. Wkrótce po Rewolucji Październikowej przesiąknięta głęboką nienawiścią do rewolucji i młodego państwa radzieckiego wraca do kraju, gdzie po niedługim okresie angażuje się do pracy w Ministerstwie Spraw Zagranicznych. Praca ta, jak sama później przyznaje, niezbyt ją porywała, ale ze względu na brak perspektyw trzymała się jej kurczowo. Wkrótce jednak po przewrocie majowym 1926 r. Piłsudski przypomina sobie [o] istnieniu Iłłakowiczówny i od tego czasu aż do I93o r. zostaje sekretarką osobistą Piłsudskiego. Po kilku latach Piłsudski znużony jej kapryśnym usposobieniem zaczyna patrzeć na nią niechętnym okiem. Wreszcie Iłłakowiczówna zmuszona jest opuścić stanowisko. Ukojenie po tym dość przykrym incydencie znajduje poetka w oficjalnych wyjazdach za granicę z odczytami o ówczesnej „mocarstwowej" Polsce, połączonych z popularyzowaniem swoich wierszy.

Najboleśniejszym dla niej ciosem była śmierć „ukochanego” Marszałka w I935 r. Napisała o tym później w ten sposób:

\section{》I tam [po]między tymi niezasłużonymi a panem Marszałkiem, wśród rąk trzymających się trumny, pozostało moje serce ${ }^{49}$.}

Oprócz problemów religijno-społecznych stanowiących przeważającą większość tematów jej utworów, dość poczesne miejsce zajmuje tzw. poezja i publicystyka polityczna.

Cechą charakterystyczną tej dziedziny twórczości Iłłakowiczówny jest nienawiść do Związku Radzieckiego, datowana jeszcze z czasów pobytu w nim, oraz ślepa i bezgraniczna wiara w Piłsudskiego i cały obóz sanacji. O tym, jak silna była nienawiść do młodego państwa radzieckiego, świadczą jej pozbawione wprost sensu i trzeźwości utwory nacechowane bezgraniczną głupotą i wymysłami, wzorowanymi zresztą na oficjalnej propagandzie i oszczerstwach kół rządzących Polski sanacyjnej. Wśród tej części twórczości wyróżniają się: Opowieść o moskiewskim męczeństwie napisana $\mathrm{w} 1927 \mathrm{r} .^{50}$ Jest ona poświęcona pamięci ks. Butkiewicza $[\text { sic! }]^{5 \mathrm{I}}$, rozstrzelanego przez władzę radziecką za kontrrewolucyjny spisek, i stanowi haniebny, niegodny pióra poety, paszkwil na Lenina i władzę radziecką. O wa rtości tych bredni niech świadczy następujący ustęp tego „poematu”:

49 Eadem, Ścieżka obok drogi, op. cit., s. 336. W oryginale nie ma podziału na wersy.

50 Eadem, Opowieść o moskiewskim męczeństwie, z tomu: Oporwieść o moskierwskim męczeństrwie. Ztoty wianek, op. cit., w: eadem, Poezje zebrane, op. cit., t. 1, s. 511-524. Dedykacja: „Pamięci księdza Konstantego Budkiewicza poświęcona”.

51 Właśc. Budkiewicza. 


\section{I.}

W Moskwie z białego kamienia,

ciosanej, murowanej

na stolicy dzierżawnej,

siadł Lenin zadumany;

a u progu sali

pachołkowie, katy i czerwoni żołnierze stali.

Przez okno widniały kopuły, mury i kamienie,

a obok były - katownia i sąd, i więzienie.

II.

O czym tak myśli władca i z rana, i na noc?

Widzi mu się - jeszcze trocha i znowu Wielkanoc,

to mu spokoju nie daje,

że Bóg ciągle zmartwychwstaje:

„Tylem go zabił razy - i grzechem śmiertelnym

i nahajką, i z brauninga

i oprawców moich butem dzielnym!

Zabiłem go tylekroć - ile chwil w mym wieku

[i w kobiecie, i w dziecięciu, i w każdym człowieku;

w każdym, kto mój poddany,

leży Bóg martwy i ukrzyżowany,

a jednak przy każdym święcie

znów powstaje niepojęcie”!

I aż się na twarzy samodzierżca zmienia

aż blednie i zgrzyta, i cały się zapienia... ${ }^{2}$

Ton tego ohydnego i oszczerczego paszkwilu utrzymany jest w tym samym tonie do końca.

O tym, że Iłłakowiczówna wybrała sobie szczególnie proces ks. Butkiewicza i spółki za temat swych paszkwili na Związek Radziecki, świadczy drugi wiersz napisany w 1923 r., pt. Dusza księdza Butkiewicza ${ }^{53}$.W wierszu tym autorka dochodzi do tego, że pasuje księdza Butkiewicza na... bohatera narodowego, który podobnie jak pierwotni chrześcijanie zginął „śmiercią męczeńską” w „obronie” wiary chrystusowej54.

52 K. Iłłakowiczówna, Opowieść o moskiewskim męczeństwie, w: eadem, Poezje zebrane, op. cit., t. 1, s. $511-512$.

53 Eadem, Dusza księdza Budkiewicza, z tomu Stowik litewski, w: eadem, Poezje zebrane, op. cit., t. 2, s. 546. Przypis: „Stracony w Moskwie 2 kwietnia 1923 r. po procesie arcybiskupa Cieplaka”.

54 Cenzor używa małej litery. 
Nie bez znaczenia w całej tej działalności oszczerczej na Związek Radziecki jest tłumaczenie w 1924 r. arcyreakcyjnej [sic'] książki niejakiego kapitana Mac Cullagha'a [sic!'] pt. Prześladowanie chrześcijaństwa przez bolszewizm rosyjski ${ }^{55}$. Pozycja ta, będąca rzekomo „naoczną” relacją autora z procesu ks. Butkiewicza stanowi zbiór najbardziej kłamliwych historyjek i oszczerstw na temat rzekomego ucisku religii w Związku Radzieckim.

Oprócz tego Kazimiera Iłłakowiczówna „przyczynia się” na polu propagandy antyradzieckiej szeregiem okolicznościowych wierszyków, a raczej paszkwili przebranych za nieudolne zresztą rymy [sic!]. Do nich należą m.in. Widzenie ${ }^{56}-$ wiersz poświęcony dzieciom z radzieckiego więzienia, List polskiego dziecka do Hoovera ${ }^{57}$ oraz wiele innych, których nie sposób tu wyliczyć.

Jeżeli chodzi o drugą stronę jej twórczości politycznej (ślepa i bezgraniczna wiara w Piłsudskiego), to wyróżniają się Wiersze belwederskie (1936) ${ }^{5^{8}}$ poświęcone Piłsudskiemu, Wiersze o Marszatku Pitsudskim ${ }^{59}$, wśród których dużo jest wierszy dla dzieci. O wymowie tych wierszy niech świadczą dwa wybrane spośród nich:

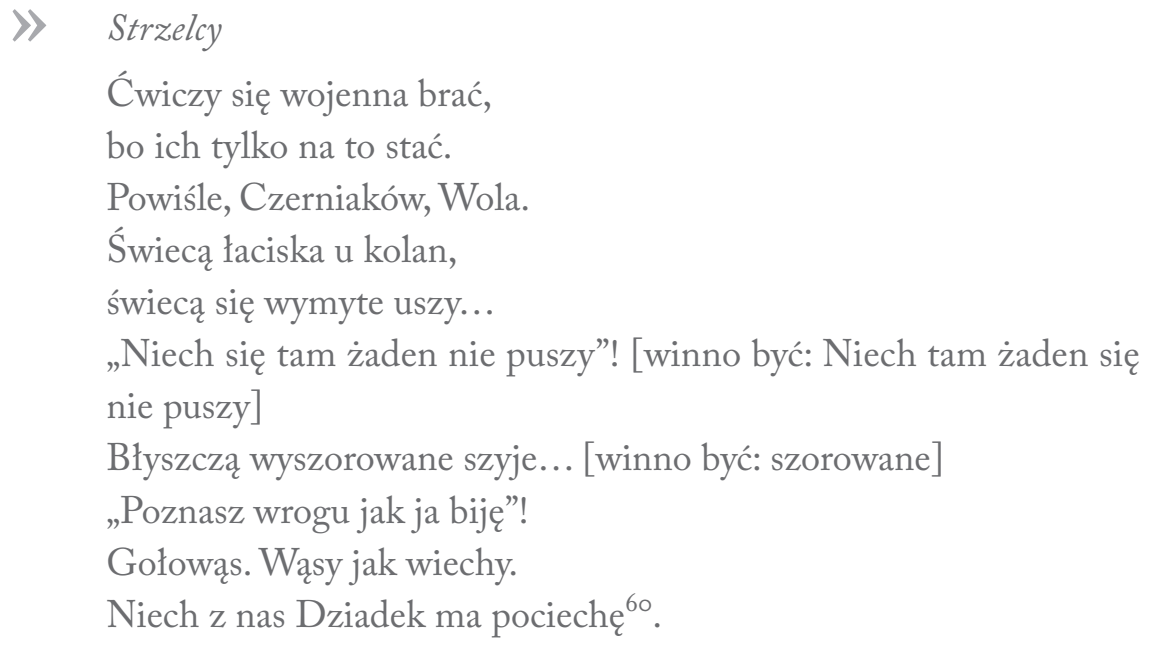

55 F. Mac Cullagh, Prześladowanie chrześcijaństwa przez bolszewizm rosyjski. [Studium], tlum. K. Iłłakowiczówna, Wyd. Księży Jezuitów, Kraków 1924.

56 Eadem, Widzenie, z tomu Ptaczacy ptak, w: eadem, Poezje zebrane, op. cit., t. 1, s. 667.

57 Eadem, Wprawki. List polskiego dziecka do Hoovera, z tomu Popiót i perty, w: eadem, Poezje zebrane, op. cit., t. 2, s. 269.

58 Eadem, Wiersze belwederskie (cykl w obrębie tomiku Stowik litewski), w: eadem, Poezje zebrane, op. cit., t. 2, s. 469-483.

59 Eadem, Wiersze o Marszatku Pitsudskim. 1912-1935, w: eadem, Poezje zebrane, op. cit., t. 2, s. 583-627.

60 Eadem, Strzelcy, z tomu Ballady bohaterskie, w: eadem, Poezje zebrane, op. cit., t. 2, s. 334. 


\section{Pomnik}

Nie trzeba pomnika! To co tu widzicie,

Ty, mistrzu, odlej

Marszałek Piłsudski całym swoim życiem

za nas się modli.

Nie trzeba pomnika, nie trzeba wieńca;

niebo całe nad nim w zorzy rumieńcach;

[rośnie murawa, szemrze rokita],

pod każdą piędzią ziemi - żołnierz zabity,

żołnierz zabity za Ojczyznę,

a każdy się do Wodza przyzna ${ }^{6}$.

Najważniejszą jednak pozycją Iłłakowiczówny z tego zakresu jest Ścieżka obok drogi z $1939 \mathrm{r}^{62}$ dla dorastających panienek z tzw. dobrych domów, poświęcona jej karierze u Piłsudskiego, tchnąca bezgranicznym uwielbieniem i ślepą wprost wiarą w niego. Przykładem i drogowskazem przy pisaniu tych broszur było nie co innego, jak najbardziej głupi pamiętnik w dziejach Polski, a mianowicie Strzepy meldunków Sławoja Składkowskiego ${ }^{63}$. Według Iłłakowiczówny Strzępy meldunkórw cechuje:

\Wyeliminowanie własnej osoby, lekkie i niewidoczne; wielka miłość powściągana twardą ręką aż do ostatnich rozdziałów - nie, nie znajdę lepszego wyrażenia jak postawa! - tak postawa wobec tematu - oto zalety, które pewnie niechcący, wynikłe wprost z charakteru piszącego, wysuwają tę książkę na czoło naszej literatury pamiętnikarskiej ostatnich czasów ${ }^{64}$.

O tym, że Iłłakowiczówna miała „oryginalny” pogląd na niektóre sprawy, świadczy jej wypowiedź o wypadkach majowych w iz lat post factum:

\Jako ogólną uwagę o wypadkach majowych dodać należy, że wydobyły one kraj z nieporządku i niemoralności politycznej, były więc

61 Eadem, Pomnik, z tomu Ballady bohaterskie, w: eadem, Poezje zebrane, op. cit., t. 2, s. 340.

62 Eadem, Ścieżka obok drogi, op. cit.

63 F. Sławoj Składkowski, Strzępy meldunków, Instytut Badania Najnowszej Historii Polski, Warszawa 1936.

64 K. Iłłakowiczówna, Ścieżka obok drogi, op. cit., s. 9-10. 
nadzwyczaj w skutkach zbawienne. W pierwszej jednak chwili wielu ludzi nie zdawało sobie sprawy $z$ tego ${ }^{65}$. (? $)^{66}$

Z tego widać, że kilka lat służby u Piłsudskiego nie pozostało bez echa. Mówi zresztą sama o tym: „Te cztery lata utrwaliły we mnie w sposób niezrozumiały i irracjonalny zupełną, żarliwą i bezgraniczną wiarę w Józefa Piłsudskiego" ${ }^{7}$. Sądzę, że wszelkie komentarze są zbyteczne.

Jeżeli chodzi o ocenę polityczną Poezji 1940-I954 wydanych w I954 r. przez PAX, to składają się na nie wiersze pisane w Rumunii oraz w Polsce Ludowej. Wśród wierszy zupełnie dla nas obojętnych ze względu na tematykę religijną, przepojonych głębokim mistycyzmem znalazły się i takie, które są dla nas absolutnie nie do przyjęcia i z cenzorskiego punktu widzenia stanowią rzeczy interpretacyjne [sic!]. Do takich należą Wiersze braterskie:

\Jeden wiatr w polu wiał, drugi wiatr $\mathrm{w}$ sadzie grał...

\section{Julian Tuwim}

\section{(ZMROZIŁ MRÓZ)}

Zmroził mróz bratki ozdobne, do ciebie i do mnie niepodobne, [winno być: podobne]

jeszcze dziś rano.

Zwarzone wsparły się wszystkie

twarzyczkami o twarde listki

bukszpanu.

Była jesień długa i łagodna,

do ciebie i do mnie podobna,

słoneczna.

Spadły na nią szron i gołoledź...

I tego nie można przeboleć

ani uleczyć!

Bo wichrowie - zachodni i wschodni-

niepodobni, ach, niepodobni

do ciebie ni do mnie...

\section{Ibidem, s. 114.}

66 Pytajnik dopisany odręcznie.

67 K. Iłłakowiczówna, Ścieżka obok drogi, op. cit., nie udało się zlokalizować strony cytatu, który prawdopodobnie jest nieprecyzyjny. 
Gdy się zetkną, zewrą, załamią, znowu wystrzelimy bratkami ale niepomni... Ale na grobie ${ }^{68}$.

Zalatuje tu wyraźnie AK-owską teorią o dwóch wrogach, przedłużoną na nasze czasy.

\section{1) Wiersz na styczeń 1944 \\ Przebacz wrogom, wyrzeknij się zemsty, \\ bo nie ujrzysz gwiazdy betlejemskiej.}

Będzie stała w górze - płomień biały

nie dla Ciebie, serce skamieniałe!

Chóry będą nad Bożą kolebką,

lecz nic nie drgnie w twojej krwi zakrzepłej.

Przejdzie obok Ciebie Boże Narodzenie,

Ziemio zbrodni, kainowa ziemio,

bez pokuty i bez miłosierdzia

rozdzierana i rwąca na ćwierci

wołająca groźnie i rozpacznie

za krew bratnią o nową krew bratnią ${ }^{69}$.

Charakterystycznym zwłaszcza dla nas jest fakt, że w Poezjach, obejmujących przecież okres dziesięciolecia Polski Ludowej, nie ma żadnego wiersza, który wskazywałby na afirmację naszej rzeczywistości przez poetkę. Wszystkie wiersze, również i najnowsze, przepojone są mistyką religijną, pełną westchnień i zadumy nad wiatrem, kontemplacji i rozmyślań nad przyrodą i jej zjawiskami. Należy jednak z drugiej strony podkreślić duże wyczulenie poetki na poetyckość faktu i rzeczy, na liryzm spraw powszedniego dnia chłopów, Cyganów, dzieci, biedoty wiejskiej ujawniające się zwłaszcza w wierszach pisanych w czasie pobytu w Rumunii.

68 Eadem, Zmrozit mróz, z tomu Poezje 1940-1954, cykl: Wiersze braterskie, w: eadem, Poezje zebrane, op. cit., t. 3, s. 129.

69 Eadem, Wiersz na styczeń 1944 roku, z tomu Lekkomyślne serce, w: eadem, Poezje zebrane, op. cit., t. 3, s. 274 . 
Inaczej jednak przedstawia się sprawa, jeżeli chodzi o zgłoszone niedawno do kontroli w Pallotinum [sic!] Wiersze religijne, składające się z wierszy wybranych z całego dorobku poetyckiego Iłłakowiczówny. Problematyka ich jest - jak i cała twórczość poetki - bardzo różnorodna, począwszy od wierszy poruszających wyłącznie problematykę religijną, a skończywszy na takich, które absolutnie nic wspólnego $\mathrm{z}$ religią nie mają, bądź też słownictwo religijne jest u [sic!] nich tylko przykrywką do głoszenia całkiem świeckich celów. Do tych ostatnich należy zwłaszcza Wybraniec poświęcony Piłsudskiemu, a zamieszczony w zbiorku pt. Wiersze o Marszatku Pitsudskim (1936) ${ }^{70}$.

\section{》Wybraniec}

Bóg mnie powołał przez ogień, przez mrok, przez ciszę;

Bóg mnie powołał... Głosy jego surm słyszę...

Piętrzy się rafa zalewu [winno być: fala]

od płomienia i śpiewu,

od piorunów, które są jak snop wężów w Jego ${ }^{7 \mathrm{I}}$ prawicy,

od gromu, który ślepnie przy Jego źrenicy.

Bóg mnie powołał, mnie, nędzę i niewolnika, jak rycerzy - Bayarda i Zawiszę, jak królów - Konstantyna i Ludwika jak świętych - Piotra, Magdalenę, Krzysztofa...

Bóg mnie powołał!... O, któżby się nie cofał... ${ }^{72}$

Całkiem chyba dwuznaczny jest wiersz Walka zamieszczony w tym samym zbiorze:

\Tablice nowych praw Szatan ze złota wykuł:

„Oto jest Zakon Czasu, pokłoń się, niewolniku, pokłoń się, plemię tchórzliwe, słabe i nienawistne, a ja ci jarzmo włożę i pętlę na szyi zacisnę".

Ale myśmy powstali zgodnie i skoczyli Złemu do oczu, a każdy z nas tchnienie Boże we włosach zjeżonych poczuł, a w oczach bijących męstwem krył każdy zimną grozę na myśl o wrogu świata z gotowym w ręku powrozem ${ }^{73}$.

70 Wybraniec pochodzi z tomu $Z$ gtębi serca i jest przedrukowany w wydaniu Bąka z 1949 r. Nie ma go w wydaniu PAX-owskim ani w edycji Albertinum. Warto zauważyć, że nie jest to wiersz o Piłsudskim.

71 Cenzor konsekwentnie stosuje minuskułę.

72 K. Iłłakowiczówna, Wybraniec, z tomu Z głębi serca, w: eadem, Poezje zebrane, op. cit., t. 2, s. 29.

73 Eadem, Walka, z tomu $Z$ gtębi serca, w: eadem, Poezje zebrane, op. cit., t. 2, s. 28. 
Charakterystycznym również dla tego rodzaju wierszy, które z religią mają mało wspólnego, są wiersze Styszycie jak się Polska modli oraz Dzwony zadumane ${ }^{74}$. W pierwszym z nich autorka pyta:

$$
\begin{aligned}
& \text { (...) } \\
& \text { Czy słyszycie żałobne wołanie } \\
& \text { Monarchini Polskiej z Częstochowy: } \\
& \text { [„Czy już tron mój złocisty gotowy?] } \\
& \text { Czy już włócznie błyskają na łanie? } \\
& \text { Czy już widać, słychać z mojej wieży } \\
& \text { blask i tętent husarskich rycerzy?!75 }
\end{aligned}
$$

Te nutki tęsknoty, oczekiwania dawnej szlacheckiej świetności i szumu husarskich skrzydeł przebijają się bardzo często w twórczości Iłłakowiczówny, zwłaszcza w pierwszym jej okresie.

Dużo miejsca zwłaszcza w latach 3o-tych zajmują w twórczości Iłłakowiczówny problemy społeczne, nierówności klasowe, ciężkie położenie mas pracujących. Autorka widzi, że:

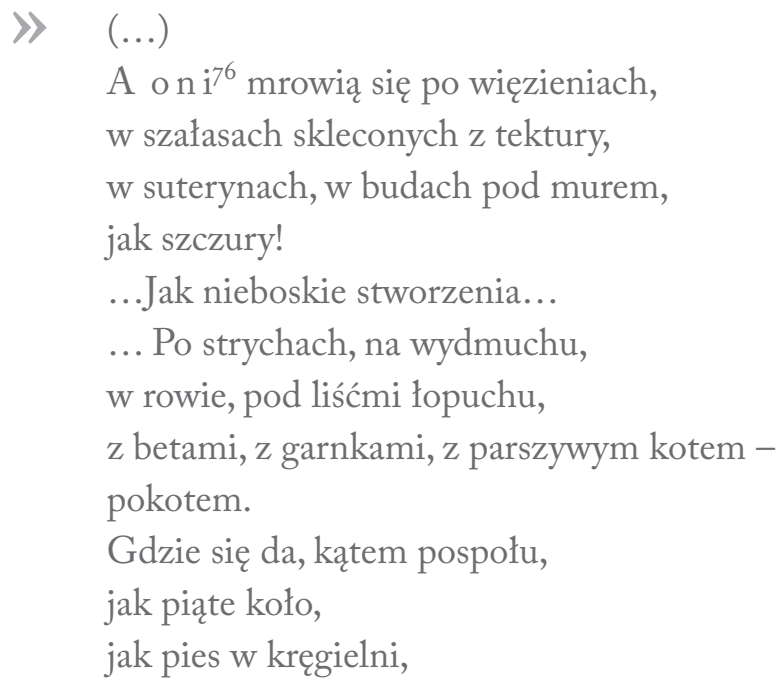

74 Właśc. Dzwony zaduszne, z tomu $Z$ gtębi serca. Wiersza tego nie ma w zbiorze Bąka ani w wydaniu Albertinum.

75 K. Iłłakowiczówna, Styszycie jak się Polska modli, z tomu Trzy struny, w: eadem, Poezje zebrane, op. cit., t. 1, s. 160-161. To druga strofa $z$ siedmiu.

$76 \mathrm{~W}$ całym przywołanym fragmencie brak podkreślenia. 
nie ukojeni, głodni, w chorobie śmiertelnej, we wszach, zaraźliwych wrzodach - nad nami wysoko, głęboko pod domami, pod spodem, wszędzie... tuż obok.

Ale jednak:

$\gg \quad(\ldots)$

Nie o rząd tu chodzi, ni magistrat, ni wyborcze zawracanie głów, nie o jedną ustawę więcej...

Chodzi o to, żeś winien [ty] zgubie tysięcy, ty sam człowieku.

(...)

Nie pomoże ni rząd, ni sąd, nie wyręczy cię żaden magistrat. Sprawa jest czysta:

Człowieku, zmyj z duszy trąd, przypomnij świętą powinność - miłosierdzie nagłe i czynne. Nie bilet na raut lub herbatkę, ale dzieło osobiste, sąsiedzkie; w sprawie brudnych szmat dziecku.

Dojrzeć, czy położnica na strychu nie dygoce pod kupą wiórów, pomóc radą umiejętną a cichą malarzowi zaszczutemu przez biura... [winno być: mularzowi]

a dalej:

$\gg \quad(\ldots)$

Nie szukajcie, mściciele,

winowajców po urzędach, ni fabrykach, bośmy zgromadzeni - w kościele.

Przed kościól, zbór i cerkiew idź, tłumie zawszony! $\mathrm{Tu}$, gdzie słowa Chrystusa lecą jak róże z ambony, 
żądaj swych praw, niech żaden z nas się nie umyka, bo w naszej leży mocy, na naszym sumieniu, by one róże zebrać i w chleb je zamieniać77.

Podobne w swojej wymowie są $\mathrm{i}$ inne wiersze poruszające problemy społeczne (Kolęda Marianny, Ballada o śpiewającym nożowcu) ${ }^{7}$. Filantropia jako główny cel i bezsilność wobec ludzkiej nędzy - oto wymowa liryki społecznej Iłłakowiczówny. O tym zresztą mówi sama Iłłakowiczówna w swej „sławnej” Ścieżce obok drogi:

\Już mówiłam: to nie rząd, nie samorząd i nie ustrój może załatwić. To musi załatwić każdy człowiek po sąsiedzku, po chrześcijańsku. Innej rady nie $\mathrm{ma}^{79}$.

Te rzekome akcenty demaskatorskie, o których tyle mówi przedmowa do Wierszy religijnych, w porównaniu $\mathrm{z}$ wymową wszystkich tych wierszy tracą na znaczeniu i przyczyniają się tylko do odwracania uwagi od walki rewolucyjnej.

\section{$\mathrm{X}$}

Co można powiedzieć o warsztacie poetyckim Kazimiery Iłłakowiczówny?

Trzeba przyznać, że wiersze są pełne prostoty i sprawiają na pierwszy rzut oka wrażenie naiwności, niedbalstwa lub nawet nieudolności. Przykładem tego może być chociażby wiersz Byty lilie:

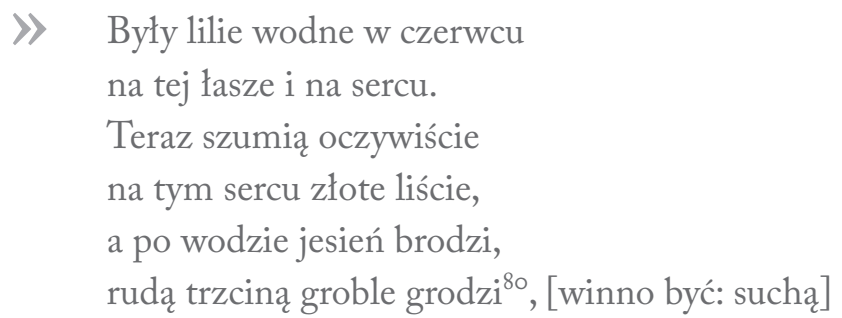

77 Fragment poematu Do chrześcijan, z tomu Stowik litewski, w: eadem, Poezje zebrane, op. cit., t. 2, s. 493-496. Utwór wywołał, po swoim pierwodruku w „Pionie” w 1934 r., sporo kontrowersji ze względu na radykalną wymowę społeczną, za: B. Mamoń, op. cit.

78 K. Iłłakowiczówna, Kolęda Marianny, z tomu Ballady bohaterskie, w: eadem, Poezje zebrane, op. cit., t. 2, s. 370; eadem, Ballada o śpiewajacym nożowcu, z tomu Ballady bohaterskie, w: eadem, Poezje zebrane, op. cit., t. 2, s. 365.

79 Eadem, Ścieżka obok drogi, op. cit., s. 319.

80 Wiersz publikowany był w lutowej „Twórczości” z 1955 (nr 2), potem w tomie Wybór poezji z 1956 r. 
albo cykl wierszy zatytułowany $Z$ wycieczki jesiennej, zamieszczony w nr 2 „Twórczości" z $1955 \mathrm{r}^{8 \mathrm{I}}$

W poezji Iłłakowiczówny zdarzają się rymy gramatyczne, błaha często tematyka, przywodząca na myśl pamiętnik egotystki żyjącej gdzieś poza światem w kręgu wspomnień i spraw najściślej prywatnych, choć nie bardzo jasno dostrzegającej granice między jawą a sennym widzeniem. $Z$ tego też względu ocenić jej twórczość jest dość trudno i trzeba zawsze głęboko wczytać się w wiersz, aby go zrozumieć. Należy podkreślić, że ostatecznie wiersze Iłłakowiczówny napisane w 1955 r. odbiegają daleko treścią od przedwojennej twórczości i stoją na wysokim poziomie artystycznym. Przykładem tego są Liście, $Z$ dębem dąb, Past się obtok czy inne $Z$ wycieczki jesiennej:

\section{\Past sięobtok}

Pasł się obłok nad Wartą pierzasty

i więcej obłoków się pasło.

Wypily wodę czystą,

wypily Wartę bystrą.

Nie mają wody gąski,

powiędły u wierzb gałązki,

obłoki się wypasły, że aż w niebie duszno,

a nad rzeką - susza a susza.

$[\text { Rogalin } 1954]^{82}$

\section{》Liście}

...cierpliwe jesienne ścielą...

od ścieżek ubitych dzielą...

Między wierzchołkiem a niebem

kształtu letniego strzegą.

Szeleszczą po drutach, po słupach,

wiedzą, gdzie i kiedy upaść:

gąskom białym pod stopki żółte,

pastuszkom - na szlak nieobuty

i-do pieśni mnie, wyraźne jak nuty ${ }^{83}$.

81 K. Iłłakowiczówna, cykl $Z$ wycieczki jesiennej (Liście, Z dębem dąb, Wątpliwość, Byty lilie, Stokrotki, Najlepiej, Past się obtok), „Twórczość” 1955, nr 2, s. 3-4, zob. też eadem, Wybór poezji, w: eadem, Poezje zebrane, op. cit., t. 3, s. 207-213.

82 Ibidem, t. 3, s. 213.

83 Ibidem, t. 3, s. 207. 


\section{$\mathrm{X}^{*}$}

$\mathrm{Na}$ koniec nasuwa się pytanie - jak oceniana jest poezja Iłłakowiczówny przez katolicką krytykę literacką?

Należy tu podkreślić, że w ostatnich czasach w przeciwieństwie do okresu międzywojennego, kiedy na Iłłakowiczównę rzucano gromy za jej twórczość szczególnie religijną (Pliszka w jaskini lwa-M.J. Wielopolskiej) ${ }^{84}$, obecna krytyka katolicka uważa ją za jedno z najwybitniejszych piór poetyckich. Podkreśla ona patriotyzm pierwszych utworów Iłłakowiczówny, ludowość, religijność powiązaną z życiem społecznym i kulturalnym naszego narodu, demaskatorstwo (!), realizm, aspekt ogólnoludzki, oryginalność itp..$^{85}$

Krytycy katoliccy widzą w poezji Iłłakowiczówny swoistą koncepcję. Koncepcję tę charakteryzuje: tendencja do oparcia kształtu wypowiedzi poetyckiej na wzorach ludowej pieśni i gawędy, prymat wyobraźni i uczucia, koncentracja problematyki wokół zagadnień moralnych i religijnych, animizacja przyrody, fantastyka i nastrojowość, a wreszcie stylizacja „ja poetyckiego” na wieszczkę, guślarkę swojego kraju i swojego ludu ${ }^{86}$.

Ogólnie biorąc, uwagi te są na ogół trafne i słuszne. Nie należy jednak zapominać o tym, że poważna część twórczości pisarki poświęcona gloryfikowaniu sanacji i jej wodzów, pełna nienawiści do Związku Radzieckiego posiada obiektywnie szkodliwą wymowę polityczną. Dlatego też fakt pozytywnych stron w twórczości Iłłakowiczówny nie może przesłaniać tego, z czym absolutnie zgodzić się nie możemy.

Wszystko to wskazuje, że przy ocenie poezji Iłłakowiczówny widzieć należy obie strony jej twórczości.

/-/K. Królik

\section{Bibliografia:}

I. Materiaty archiwalne:

AAN, GUKPPiW, sygn. 169;

AAN, GUKPPiW, sygn. 386, t. 31/126;

AAN, GUKPPiW, sygn. 420, t. 165/4.

84 J.M. Wielopolska, Pliszka w jaskini lwa. Rozważania nad ksią̇ka Ittakowiczówny „Ścieżka obok drogi”, druk J. Zielony, Warszawa, 1939.

85 Kazimierz Królik wyraźnie korzysta tu ze wstępu Z. Pędzińskiego do wydania Wierszy religijnych 1912-1954, op. cit., s. 5-10.

86 Najprawdopodobniej autor odwołuje się tu do artykułów: P. Grzegorczyka, Wiersze Ittakowiczówny, „Tygodnik Powszechny” 1950, nr 7, s. 6 (recenzja wydania Bąka) i B. Mamonia, op. cit. (artykuł zainspirowany przez wydanie PAX-owskie). 
III $\cdot$ VARIA

384

\section{Bibliografia podmiotowa (W UKŁADZie ChronologicZNYM):}

\section{a. Utwory K. Iłłakowiczówny:}

Ikarowe loty. [Wiersze], „Książka”, Kraków 1908;

Wici. Cieniom roku 1914 poświęcone. [Wiersze], Gebethner i Wolff, Warszawa 1914;

Trzy struny [Wiersze], Skład główny Księgarni Polskiej, Piotrogród 1917;

Kolędy polskiej biedy. (W wigilię powrotu). [Wiersze], Praca, Piotrogród 1917;

Bajeczna historia o królewiczu La-f-Czaniu, o żotnierzu Soju i o dziewczynce Klio. [Powieść dla dzieci], E. Wende i Sp., Warszawa 1918;

Śmierć Feniksa. [Wiersze], Ignis, Warszawa 1922

Rymy dziecięce. [Wiersze], K. Stryjeński, Kraków 1922;

Potów [Wiersze], J. Mortkowicz, Warszawa 1926;

Obrazy imion wróżebne [Wiersze], Hoesick, Warszawa 1926;

Opowieść o moskiewskim męczeństwie [Poemat]; Ztoty wianek [Wiersze], Hoesick, Warszawa 1927;

Ptaczacy ptak [Wiersze], Hoesick, Warszawa 1927;

Zwierciadto nocy [Wiersze], J. Mortkowicz, Warszawa 1928 (antydatowane 1927);

Czarodziejskie zwierciadetka. 50 wróżb wierszem, Księgarnia św. Wojciecha, Poznań 1928;

Z gtębi serca [Wiersze], Gebethner i Wolff, Warszawa 1928;

Popiót i perty [Wiersze], Hoesick, Warszawa 1929;

Ballady bohaterskie [Wiersze], Ossolineum, Lwów 1934 (antydatowane 1933);

Wesote wierszyki, Gebethner i Wolff, Warszawa 1934 (antydatowane 1933);

Stowik litewski. Poezje, Gebethner i Wolff, Warszawa 1936;

Wiersze o Marszatku Pitsudskim. 1912-1935, Główna Księgarnia Wojskowa, Warszawa 1936;

Ścieżka obok drogi, Towarzystwo Wydawnicze Rój, Warszawa 1939;

Wiersze bezlistne. Zbiór poezji z lat 1936-1941, Komitet Obywatelski dla Spraw Opieki nad Uchodźcami Polskimi na Węgrzech, Budapeszt 1942;

Wiersze wybrane. 1912-1947, posł. W. Szewczyk, W. Bąk, Łódź 1949;

Pisarze wobec dziesięciolecia, „Nowa Kultura” 1954, nr 12, s. 3;

Poezje. 1940-1954, PAX, Warszawa 1954;

Wiersze religijne. 1912-1954, przedm. Z. Pędziński, Albertinum, Poznań 1955;

Z wycieczki jesiennej [cykl] (Liście, Z dębem dąb, Watpliwość, Byty lilie, Stokrotki, Najlepiej, Past się obtok), „Twórczość” 1955, nr 2, s. 3-4;

Wybór wierszy, wyb. W. Kubacki, PIW, Warszawa 1956;

Z rozbitego fotoplastykonu. [Proza poetycka], PIW, Warszawa 1957;

Lekkomyślne serce. [Wiersze], Czytelnik, Warszawa 1959;

Poezje zebrane, zebrali, oprac. i bibliogr. sporządzili J. Biesiada, A. Żurawska-Włoszczyńska, wstęp J. Ratajczak, I. Chmielewska, t. 1-4, Torun 1999. 


\section{b. Przekłady i opracowania autorstwa Kazimiery Iłłakowiczówny:}

Mac Cullagh F., Prześladowanie chrześcijaństwa przez bolszewizm rosyjski. [Studium], Wyd. Księży Jezuitów, Kraków 1924;

Ady E., Wybór poezji, przedm. L. Keviczky, sł. wst. S. Vincenz, Biblioteka Polska, Budapeszt 1943;

Āprily L., Wybór poezji, tłum. K. Iłłakowiczówna, J. Kot, S. Vincenz, Biblioteka Polska, Budapeszt 1943;

Carnegie D., Jak uszczęśliwiać innych i być szczęśliwym?, streściła K. Iłłakowiczówna, Albertinum, Poznań 1948

Tamasi A., Abel w puszczy. [Powieś́c], cz. 1-2, Wiedza, Warszawa 1948;

Lestyan S., W Bukowińskiej Puszczy. [Opowieśc przygodowo-przyrodnicza dla modzieży], tłum. i przyp. K. Iłłakowiczówna, Nasza Księgarnia, Warszawa 1953;

Tołstoj L., Anna Karenina. Powieść, t. 1, 3-4, PIW, Warszawa 1952-1953;

Schiller F., Don Carlos. Poemat dramatyczny, PIW, Warszawa 1954;

Goethe J.W., Egmont. Tragedia, oprac. Z. Ciechanowska, Ossolineum, Wrocław 1956.

\section{Bibliografia PRZEDMiotowa:}

Budrowska K., Werwnętrzne pismo cenzury. „Biuletyn Informacyjno-Instrukcyjny w latach 1952-1955, w: eadem, Studia i szkice o cenzurze w Polsce Ludowej w latach 40. i 50. XX wieku, Białystok 2014, s. 95-106;

Dorosz B., Kazimiera Ittakowiczówna, w: Wspótcześni polscy pisarze i badacze literatury. Stownik biobibliograficzny, t. 3, red. J. Czachowska i A. Szałagan, Warszawa, 1994, s. 294-299;

Grzegorczyk P., Wiersze Ittakowiczówny, „Tygodnik Powszechny” 1950, nr 7, s. 6;

Kondek S.A., Wtadza i wydawcy. Polityczne uwarunkowania produkcji ksiażek w Polsce w latach 1944-1949, Warszawa 1993;

Mamoń B., O wierszach Ittakowiczówny, „Tygodnik Powszechny” 1955, nr 15, s. 12, 15;

Molnar I., Kazimiera Ittakowiczówna a język i literatura węgierska, w: Z dziejów polsko-węgierskich stosunkóww historycznych i literackich, red. I. Csaplaros, A. Sieroszewski, Warszawa 1978, s. 189-196;

Sławoj Składkowski F., Strzępy meldunków, Instytut Badania Najnowszej Historii Polski, Warszawa 1936;

Wielopolska J.M., Pliszka w jaskini lwa. Rozważania nad ksiaż̇ka Ittakowiczówny „Ścieżka obok drogi”, druk J. Zielony, Warszawa 1939.

SŁowA KLUCze: cenzura, Kazimiera Iłłakowiczówna, materiał źródłowy, GUKPPiW, $1955 \mathrm{r}$. 


\section{Kamila Budrowska}

„Aвout the works of Kazimiera İeakowiczówna”. Archival materials from the Central Office of the Press, Publications and Events' CONTROL FROM I 955

The source material is taken from the Central Office of the Press, Publications and Events' Control documents maintained in the Archives of Modern Records in Warsaw. It contains a few-page long article - a synthetic description of Kazimiera Iłłakowiczówna’s biography and her creative path - published in the July issue of the inner censorship circular from 1955, in which the new rules on how to control the oeuvre which previously was banned from printing are explained.

The introduction is a description of how censorship dealt with the works of Iłłakowiczówna. The author refers to other documents from the Archives of Modern Records, the press from the epoch, the collections published in the $40^{\mathrm{S}}$ and $50^{\mathrm{s}}$ and compares them to the source materials, what allows her to come to several conclusions. She confirms the existence of the volume of collected works which was submitted for publication at Wydawnictwo Zachodnie in the summer of I948. She also discovers that the ban on printing was not imposed on several poems published in the Christian press and on interviews in the press. The author also proves that the suspension on the ban for publication comes in 1954 and is one of the first signs of thaw in the Central Office of the Press, Publications and Events' Control.

KEY worDs: censorship, Kazimiera Iłłakowiczówna, source materials, GUKPPiW, 1955 